\title{
Nucleic acids and growth of Calanus finmarchicus in the laboratory under different food and temperature conditions
}

\author{
Melissa M. Wagner*, Robert G. Campbell, Carla A. Boudreau, Edward G. Durbin \\ Graduate School of Oceanography, University of Rhode Island, Narragansett, Rhode Island 02882, USA
}

\begin{abstract}
We examined the effects of food concentration and temperature on nucleic acids and protein content of Calanus finmarchicus in order to evaluate the use of RNA as a growth rate index for this species. We measured RNA, DNA, and protein content of copepods reared from egg to adult

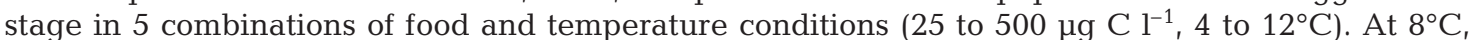
DNA, RNA and protein content and RNA:DNA differed among food treatments during Stages N6 through to adult female. Protein:DNA ratios and RNA:protein ratios were significantly different among food levels for only 3 of the 8 stages examined. At excess food, DNA, RNA, and protein content and RNA:DNA ratios were inversely related to temperature for most stages from C1 onward, but the effect of temperature was relatively small over the range of temperatures investigated. The RNA:DNA and protein:DNA ratios increased with developmental stage whereas the RNA:protein ratio and growth rates (measured in terms of protein, nitrogen, DNA, and carbon content) declined with increasing stage. Although the relationship of RNA:DNA to growth rates was stage-specific, the two were related when standardized for temperature and developmental stage. RNA:protein ratios were directly related to growth rates regardless of stage, and the slope of the relationship increased with increasing temperature in a nonlinear fashion. Our results emphasize the importance of temperature and developmental stage for the relationship of growth rates to RNA concentration and RNA:DNA ratios. We propose 2 ways to estimate in situ growth rates of $C$. finmarchicus from RNA:DNA or RNA:protein ratios and environmental temperature.
\end{abstract}

KEY WORDS: Copepod · Growth $\cdot$ Nucleic acids $\cdot$ RNA:DNA $\cdot$ Zooplankton $\cdot$ Calanus Resale or republication not permitted without written consent of the publisher

\section{INTRODUCTION}

Ribonucleic acid (RNA) content and RNA:DNA ratios have been used for several decades to monitor nutritional condition and to estimate growth rates of a variety of terrestrial and marine organisms at all trophic levels. The technique has been applied to phytoplankton (Berdalet \& Dortch 1991), zooplankton (e.g. Sutcliffe 1965, Båmstedt 1983), larval fish (e.g. Buckley 1984, Caldarone \& Buckley 1991, Clemmesen 1993), and to juvenile and adult fish tissues (Thorpe et al. 1982, Goolish et al. 1984). RNA concentration and

*E-mail: mwagner@gso.uri.edu nucleic acid ratios have also been used to study growth and nutrition of larval, juvenile, and adult stages of several benthic invertebrates: oysters (Wright \& Hetzel 1985), the sea urchin Paracentrotus lividus (Frantzis et al. 1992), postlarvae of the lobster Homarus americanus (Juinio et al. 1992), and several crab species (Sulkin et al. 1975, Anger \& Hirche 1990, Mayrand et al. 1998).

In the past few years there has been renewed interest in ribonucleic acid (RNA) content or RNA:DNA ratios as indices of growth rates or reproductive capacity of marine copepods. Such an index would simplify the measurement of growth and egg production and would allow more extensive sampling in the field by eliminating the need for incubation of animals or re- 
peated sampling of cohorts. The earliest studies on the topic suggested that growth rates are related to RNA concentration in several species of copepods and other crustaceans (e.g. Sutcliffe 1965, 1969, Dagg \& Littlepage 1972, Båmstedt \& Skjoldal 1976, 1980), but no widely used technique emerged from that work. In recent work, RNA:DNA ratios were related to egg production rates of Paracalanus sp. (Nakata et al. 1994) and Acartia grani (Saiz et al. 1998). RNA:DNA ratios have also been shown to reflect the nutritional status of Calanus finmarchicus in the laboratory and may be useful in monitoring their physiological state in the field (Wagner et al. 1998). There is some evidence that the relationship of RNA to growth is species-specific (Dagg \& Littlepage 1972), but the apparent differences between species might result from the variety of analytical methods used by different laboratories. Buckley et al. (1999) recommended intercalibration among techniques and laboratories in order to standardize the various nucleic acid techniques used for fish larvae.

The effect of temperature on nucleic acids has been well studied in larval fish, but has received less attention in copepods. The increased rate of chemical reactions at higher temperatures means that a higher growth rate can be achieved with the same or lower RNA concentration, and also that the RNA concentration associated with maximal growth rates declines with increasing temperature (e.g. Buckley 1984). Two studies have addressed the effect of temperature on nucleic acids of copepods. Ota \& Landry (1984) found that RNA:DNA ratios of Calanus pacificus were higher at $8^{\circ} \mathrm{C}$ than at $15^{\circ} \mathrm{C}$, but they did not attempt to quantify the effect of temperature on RNA and its relation to growth rates. Saiz et al. (1998) reported that temperature increased the slope of the linear relationship between egg production and RNA:DNA, and they called for consideration of 3 or 4 temperatures in order to refine the technique.

The present work was part of an experiment examining the effects of food and temperature on development and growth rates of Calanus finmarchicus over its entire life cycle (Campbell et al. 2001, this issue). C. finmarchicus is the dominant copepod species of the subarctic North Atlantic Ocean. In the western North Atlantic, its range extends as far south as the Gulf of Maine-Georges Bank system, where it is the dominant copepod in terms of biomass during the late winter and spring. Because this species has recently been a target organism of the US GLOBEC Northwest Atlantic Georges Bank Study (GLOBEC 1992) and the TransAtlantic Study of Calanus finmarchicus (TASC), there has been tremendous effort to understand its population dynamics and to measure its growth and reproductive rates in various locations and in the laboratory.
This effort has provided an excellent opportunity to investigate the relationship of nucleic acids and growth in this species.

The 3 main objectives of this work were: (1) to examine the effects of food concentration on several potential biochemical condition indices (RNA:DNA, protein:DNA, and RNA:protein); (2) to quantify the effect of temperature on these indices in order to compare individuals living at different temperatures; and (3) to develop models for estimating growth rates of Calanus finmarchicus from the biochemical indices. We also examined the effects of food and temperature on body size as estimated by protein content and DNA content. RNA:DNA is an index of RNA content per cell, since the DNA content is taken to represent the total cell number and can be a proxy for biomass (Bulow 1987). Protein:DNA provides an index of average cell biomass, and RNA:protein represents the RNA concentration of an animal. In order to determine which type of growth was best represented by the biochemical ratios, we measured growth in terms of carbon, nitrogen, protein and DNA content.

\section{METHODS}

Rearing Calanus finmarchicus. The experiment took place from July to October 1996. A brief summary of the culture techniques is given here; further details can be found in Campbell et al. (2001). Calanus finmarchicus were reared in the laboratory in $100 \mathrm{l}$ plastic tanks, with 2 replicate tanks maintained in each of 5 experimental treatments. Three food treatments with nominal concentrations of $500 \mu \mathrm{g}$ carbon (C) per liter (high food), $50 \mu \mathrm{g} \mathrm{C} \mathrm{l}^{-1}$ (medium food) and $25 \mathrm{\mu g} \mathrm{C} \mathrm{l}^{-1}$ (low food) were kept at $8^{\circ} \mathrm{C}$. The high food treatment was intended to be far in excess of the limiting concentration in this species, which we expected could be as low as 100 to $150 \mu \mathrm{g} \mathrm{C} \mathrm{l}^{-1}$ based on previous work with Calanus spp. (Paffenhöfer \& Harris 1979 [their Fig. 8], Vidal 1980). Two additional temperature treatments, 4 and $12{ }^{\circ} \mathrm{C}$, were fed at the high food concentration. Cultures were begun by placing 7500 eggs into each tank with $15 \mathrm{l}$ filtered seawater. In an effort to maintain uniform grazing rates over time, the density of copepods in the tanks was decreased as they developed by removal of individuals and by dilution to larger culture volumes.

The copepods were fed a mixture of cultured phytoplankton containing 3 parts (based on carbon content) Gymnodinium sanguineum, 3 parts Heterocapsa triquetra, 3 parts Tetraselmis sp., and 1 part Oxyrrhis marina. Although the food in the experimental tanks was adjusted twice daily to the nominal phytoplankton concentrations, the average food concentrations dur- 
ing the entire experiment differed from the nominal values, especially in the high and medium food treatments. Mean food concentrations were calculated for each $12 \mathrm{~h}$ interval between feedings (Campbell et al. 2001), and averaged 333 to $390 \mu \mathrm{g} \mathrm{Cl}^{-1}$ in the high food tanks, 39 to $40 \mu \mathrm{g} \mathrm{C}^{-1}$ in the medium food tanks and 24 to $28 \mu \mathrm{C} \mathrm{C}^{-1}$ in the low food tanks over the duration of the experiment. As a rule, the mean food concentration was lower than the nominal concentration. The food concentration in one of the low food tanks strayed as high as $80 \mu \mathrm{g} \mathrm{C} \mathrm{l}^{-1}$ for several days, causing the mean for this treatment to be higher than the nominal concentration.

Sampling. The copepods in the tanks were sampled several times daily for development rates, and approximately once per stage for carbon and nitrogen content $(\mathrm{CN})$ and biochemical measurements. Details of the development rate and $\mathrm{CN}$ determinations are presented by Campbell et al. (2001).

We sampled Stages N3, N6, and C1 through C6. Although we attempted to sample each stage when nearly $100 \%$ of the copepods were in that stage, this was only achieved for the high food treatments. Since the stage distribution of the medium and low food treatments spread out over time, up to 5 stages were present simultaneously. In these cases we sampled at N3, then again when most of the individuals were N6 or C1, and approximately weekly thereafter. We sampled all stages that we estimated to contribute $10 \%$ or more to the total biomass of the sample.

After an appropriate volume was removed from each tank with a plastic beaker, the copepods were concentrated on a sieve (60 to $200 \mu \mathrm{m}$ mesh size) then anesthetized with MS-222 diluted in filtered seawater (Finquel brand, Argent Chemical, $0.58 \mathrm{~g} \mathrm{l}^{-1}$ ). The copepods were rinsed with MS-222 solution into a petri dish and were then sorted by stage. During sorting, each individual was placed in a drop of MS-222 solution on a depression slide and a video image was recorded. The video images were later used to measure the prosome length of each copepod by using image-analysis software. After videotaping, the copepods were placed in polypropylene microcentrifuge tubes and were stored at $-80^{\circ} \mathrm{C}$. The copepods were not rinsed, but were manipulated in such a way as to minimize transfer of seawater to the sample vials.

The number of individuals per vial varied with stage, since a large number of nauplii were needed to obtain a reliable signal, while copepodite stages could be analyzed individually. Nauplii were pooled in groups of 20 (N3), 10 (N4 and N5) or 5 (N6) nauplii per sample vial, and copepodite stages were sampled individually. We collected 3 replicate samples for N3 to N5, 5 replicates for N6, and 25 individuals for copepodites.
The copepod samples were analyzed for DNA and RNA concentration by the microplate fluorescent assay (MFA) described by Wagner et al. (1998). Nucleic acids were extracted by using a $1 \%$ sarcosyl (N-lauroylsarcosine) solution (Caldarone \& Buckley 1991) and were then quantified fluorometrically by using ethidium bromide and ribonuclease A (RNase). We measured total protein in the same sample homogenates by using the Bicinchoninic Acid (BCA) Protein Assay Kit (Sigma, St. Louis, MO) adapted for 96-well microplates. In order to achieve a stable endpoint and to increase sensitivity to low protein concentrations, the incubation step was modified from $30 \mathrm{~min}$ at $37^{\circ} \mathrm{C}$ to 60 min at $60^{\circ} \mathrm{C}$ (Smith et al. 1985).

Analyzing the data. In the high food treatments at 4 , 8 and $12^{\circ} \mathrm{C}$, where the stage composition of the cohorts remained relatively narrow, calculating mean values of the various biochemical variables by stage and by time was simple because each sample contained nearly $100 \%$ of one stage and each stage was sampled only once. The sole exception was Stage C 5 in the $4^{\circ} \mathrm{C}$ high food treatment, where the stage was prolonged and individuals in this stage were sampled over several weeks. In this case the copepods that remained in Stage C5 the longest seemed to have empty guts despite the high food concentration and to have large lipid stores. Also, the mean RNA:DNA ratio declined over time to levels similar to those observed by Wagner et al. (1998) in dormant Stage C5, suggesting that the copepods in the $4^{\circ} \mathrm{C}$ treatment may have been entering a resting stage. In this treatment only the first sample was counted as $\mathrm{C} 5$.

For the medium and low food treatments where several stages were often present together, and where the same stage was usually sampled on more than 1 day, mean values of each variable were calculated using all data for a stage, although they may have been collected on different days. To obtain daily means of DNA, RNA, and protein, we calculated weighted means, since the stage composition of samples taken for nucleic acid analysis sometimes differed slightly from that of the cohort. The ratios were then calculated from the daily mean DNA, RNA, and protein values.

Protein- and DNA-specific growth rates were calculated from the difference in mean protein or DNA content from one sample date to the next, as was done by Campbell et al. (2001) for carbon and nitrogen. The exponential growth rate, $g$, was determined from the relationship

$$
g=\frac{\ln B_{2}-B_{1}}{t_{2}-t_{1}}
$$

where $B_{1}$ and $B_{2}$ are the protein or DNA content at the beginning and end of each interval and $t_{1}$ and $t_{2}$ are the initial and final age. Except where noted, all 
growth rates presented in this work are forecast; that is, the growth rate for a sample refers to growth between that sample and the next, rather than growth in the interval before sampling. Since the N3 samples were collected very early in the stage and comprised first-feeding individuals and since we did not observe any differences in size or biochemical ratios among the food levels at this stage, N3 was not included in any regressions of growth or development rates against RNA.

All statistical calculations were done by using PCSAS Version 6.12 (SAS Institute Inc, Cary, NC). The effect of food on each biochemical variable was examined over the life cycle by analysis of variance (ANOVA). Because of unequal sample sizes, the tests were done by using the 'general linear models' (GLM) procedure of PC-SAS rather than the ANOVA procedure.

The data for each variable were first analyzed by 2way ANOVA to test for interactions between food level and stage. This interaction was usually significant, since the pattern of change over the stages was different among the food treatments, so the simple effects of food at each stage were analyzed by 1-way ANOVA with Tukey HSD tests to compare the food levels. Because the nauplii were pooled and the copepodite stages were sampled individually, 2 different ANOVA models were used for naupliar stages and copepodite stages. For nauplii the data unit was the tank mean for each stage, whereas for the copepodite stages the basic data unit was the individual copepod, and a nested ANOVA model was used so that the variance among individuals could be assessed while using the variance among tanks as the error term for the food effect.

Late in the development of the low food cohorts, the average food level in one of the 2 tanks increased for several days to nearly $80 \mu \mathrm{g} \mathrm{Cl}^{-1}$, exceeding that of the medium food treatment. This affected Stages C3, C4, and $\mathrm{C} 5$, increasing their growth rates and RNA content. For this reason the 2 low food cohorts were not true replicates, and data for the 'runaway' tank during this period were not included in the analysis for foodlevel effects, but are included in subsequent analyses.

\section{RESULTS}

\section{Effects of food concentration on biochemical variables of Calanus finmarchicus at $8^{\circ} \mathrm{C}$}

The mean DNA, RNA, and protein content for each stage grown at the three food concentrations at $8^{\circ} \mathrm{C}$ are summarized in Fig. 1 (A to C). DNA, RNA, and protein content increased with increasing stage, reflecting the increasing size of the copepods. Copepods in the higher food treatments tended to have significantly higher DNA, RNA, and protein content (Tukey HSD tests, $\mathrm{p}<0.05)$, but the stage at which the difference became apparent varied from N3 (RNA, Fig. 1B), to N6 (protein, Fig. 1C), to C1 (DNA, Fig. 1A). The DNA and
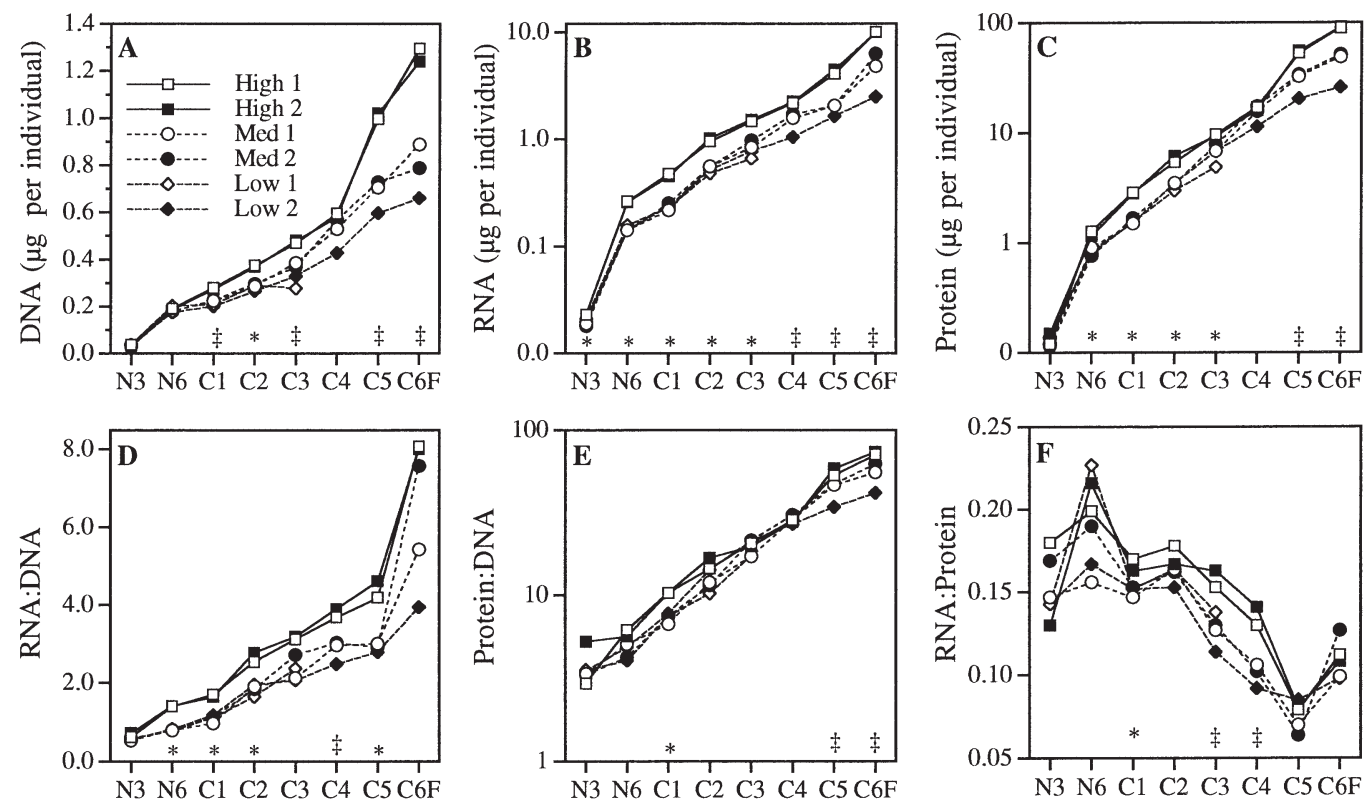

Fig. 1. Calanus finmarchicus. Biochemical measurements and ratios of 8 developmental stages in the 3 food treatments at $8^{\circ} \mathrm{C}$. Data for replicate tanks are plotted as separate series. $\$$ : stages for which all 3 treatments were significantly different; *: stages for which high food treatment was significantly higher than the others (Tukey HSD tests, $\mathrm{p}<0.05$ ) 
protein contents of copepods in the different food treatments were not significantly different at N3, as the copepods had only very recently begun to feed.

Mean RNA:DNA, protein:DNA, and RNA:protein ratios of each stage are presented in Fig. 1 (D to F). RNA:DNA and protein:DNA ratios increased with stage whereas RNA:protein ratios declined as the copepods developed. RNA:DNA and RNA:protein ratios increased sharply between C5 and C6 (Fig. 1D,F); this change is most likely to have been associated with egg production by the adult females.

RNA:DNA ratio generally differed among food treatments; from N6 onward it was usually significantly higher in the high food treatment, and sometimes differed among the 3 food levels (Fig. 1D). Protein:DNA and RNA:protein ratios were quite variable among tanks and among individuals. During most stages both of these ratios were a bit higher in the high food treatment, but significant food effects were only detected during 3 stages for each variable (Fig. 1E,F).

\section{Effects of temperature on biochemical variables at excess food concentrations}

In general, all the biochemical variables appeared to some extent to be inversely related to temperature, but the relationships and significance varied with stage (Fig. 2). Regression models for each variable as a function of temperature during each stage are shown in
Table 1. DNA content, RNA content, and RNA:DNA ratios were inversely related to temperature, but the trend was not significant until C1 or C2 ( $<<0.05)$. The effect of temperature on protein content was less clear; significant inverse relationships were observed for $\mathrm{C} 2$ and C3, but not for C4, C5, or C6F. Despite the lack of a significant functional relationship between protein and temperature for Stages C4 to adult, the protein content in one temperature treatment was often somewhat higher or lower than the others (Fig. 2C). During $\mathrm{C} 4$, the $4^{\circ} \mathrm{C}$ treatment had significantly higher protein content than the 8 and $12^{\circ} \mathrm{C}$ treatments, which were similar (1-way ANOVA with Tukey test, p < 0.05). During $\mathrm{C} 5$, however, the $12^{\circ} \mathrm{C}$ treatment appeared to be lower than the other temperatures, but the difference was not significant $(p>0.05)$. Adult females also appeared to show an inverse trend due to temperature, but the trend was not significant because of high variability among the two $4^{\circ} \mathrm{C}$ treatment tanks.

The protein:DNA, and RNA:protein ratios also tended to decline with increasing temperature (Table 1) but were significantly related to temperature for only 2 of the stages (C1 and C3, and C3 and C5, respectively).

\section{Growth rates}

The increase in mean protein and DNA content over time in each treatment tank, starting with the
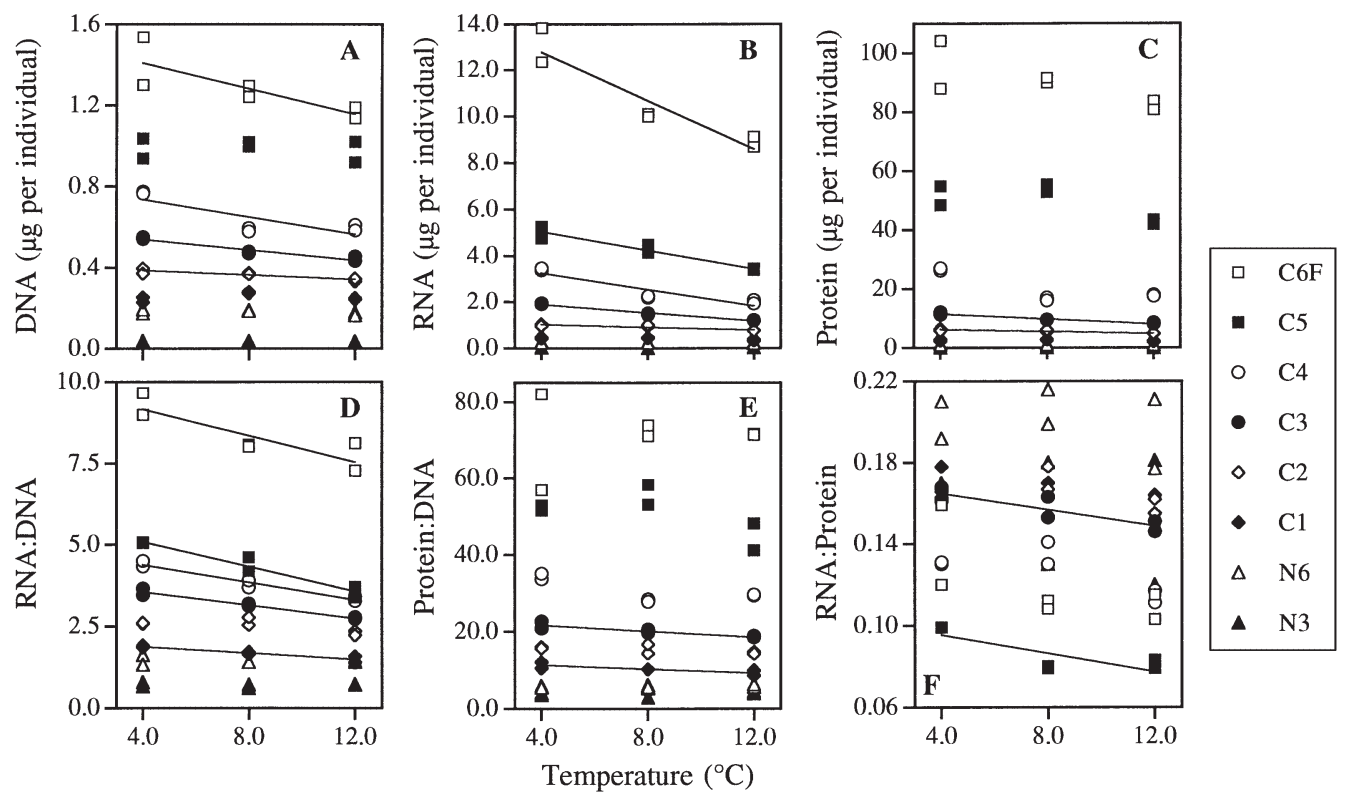

Fig. 2. Calanus finmarchicus. Effect of temperature on biochemical variables for copepods reared at 4,8 , and $12^{\circ} \mathrm{C}$ with excess food. Data are means of pooled samples (nauplii) or individuals (copepodite stages) from each of the 2 replicate tanks in each treatment. Least-squares regression lines are shown for data series with significant linear regressions against temperature 
Table 1. Calanus finmarchicus. Simple linear regression of each biochemical variable against temperature for several developmental stages cultured at 4,8 , and $12{ }^{\circ} \mathrm{C}$ with excess food. ${ }^{*}$ Significant $\mathrm{p}$-values. Model: RNA:DNA $=\mathrm{a} T+\mathrm{b} . \mathrm{n}=6$ for all stages

\begin{tabular}{|c|c|c|c|c|c|c|c|}
\hline Stage & Statistic & DNA & RNA & Protein & RNA:DNA & Protein:DNA & RNA:Protein \\
\hline \multirow[t]{4}{*}{ N3 } & $\mathrm{a}$ & $-6.25 \mathrm{E}-05$ & $-6.25 \mathrm{E}-05$ & 0.00219 & -0.00119 & 0.0498 & -0.00231 \\
\hline & $\mathrm{b}$ & 0.0372 & 0.0260 & 0.133 & 0.715 & 3.68 & 0.176 \\
\hline & $\mathrm{r}^{2}$ & 0.0117 & 0.0116 & 0.113 & 0.0051 & 0.0507 & 0.0857 \\
\hline & $\mathrm{p}$ & 0.8383 & 0.8389 & 0.5156 & 0.8935 & 0.6679 & 0.5734 \\
\hline \multirow[t]{4}{*}{ N6 } & a & -0.00163 & -0.00350 & -0.0138 & -0.00750 & 0.0313 & $-8.75 \mathrm{E}-04$ \\
\hline & $\mathrm{b}$ & 0.194 & 0.281 & 1.30 & 1.50 & 5.65 & 0.208 \\
\hline & $r^{2}$ & 0.260 & 0.606 & 0.348 & 0.0698 & 0.128 & 0.0459 \\
\hline & $\mathrm{p}$ & 0.3020 & 0.0681 & 0.2175 & 0.6128 & 0.4868 & 0.6835 \\
\hline \multirow[t]{4}{*}{ C1 } & $\mathrm{a}$ & $6.88 \mathrm{E}-04$ & -0.0111 & -0.0531 & -0.0500 & -0.256 & $-8.13 \mathrm{E}-04$ \\
\hline & $\mathrm{b}$ & 0.249 & 0.517 & 3.04 & 2.08 & 12.4 & 0.173 \\
\hline & $r^{2}$ & 0.0168 & 0.528 & 0.327 & 0.883 & 0.668 & 0.198 \\
\hline & $\mathrm{p}$ & 0.8065 & 0.1017 & 0.2360 & $0.0053^{*}$ & $0.0472^{*}$ & 0.3765 \\
\hline \multirow[t]{4}{*}{$\mathrm{C} 2$} & $\mathrm{a}$ & -0.00563 & -0.0289 & -0.160 & -0.0375 & -0.174 & $-7.50 \mathrm{E}-04$ \\
\hline & $\mathrm{b}$ & 0.0410 & 1.16 & 6.92 & 2.81 & 16.7 & 0.171 \\
\hline & $r^{2}$ & 0.794 & 0.760 & 0.751 & 0.485 & 0.383 & 0.126 \\
\hline & $\mathrm{p}$ & $0.0171^{*}$ & $0.0236^{*}$ & $0.0256^{*}$ & 0.1241 & 0.1900 & 0.4908 \\
\hline \multirow[t]{4}{*}{ C3 } & $\mathrm{a}$ & -0.0127 & -0.0892 & -0.434 & -0.102 & -0.386 & -0.00200 \\
\hline & $\mathrm{b}$ & 0.590 & 2.26 & 13.4 & 3.97 & 23.3 & 0.173 \\
\hline & $\mathrm{r}^{2}$ & 0.920 & 0.977 & 0.932 & 0.967 & 0.809 & 0.740 \\
\hline & $\mathrm{p}$ & $0.0025^{*}$ & $0.0002^{*}$ & $0.0018^{*}$ & $0.0004^{*}$ & $0.0146^{*}$ & $0.0280^{*}$ \\
\hline \multirow[t]{4}{*}{$\mathrm{C} 4$} & $\mathrm{a}$ & -0.0217 & -0.176 & -1.11 & -0.136 & -0.620 & -0.00206 \\
\hline & $\mathrm{b}$ & 0.824 & 3.95 & 29.1 & 4.94 & 35.6 & 0.143 \\
\hline & $r^{2}$ & 0.702 & 0.856 & 0.640 & 0.952 & 0.545 & 0.465 \\
\hline & $\mathrm{p}$ & $0.0374^{*}$ & $0.0082^{*}$ & 0.0560 & $0.0009^{*}$ & 0.0937 & 0.1356 \\
\hline \multirow[t]{4}{*}{ C5 } & $\mathrm{a}$ & -0.00231 & -0.200 & -1.11 & -0.191 & -0.947 & -0.00225 \\
\hline & $\mathrm{b}$ & 1.01 & 5.84 & 58.3 & 5.86 & 58.5 & 0.105 \\
\hline & $\mathrm{r}^{2}$ & 0.0287 & 0.929 & 0.468 & 0.939 & 0.344 & 0.676 \\
\hline & $\mathrm{p}$ & 0.7481 & $0.0019^{*}$ & 0.1341 & $0.0014^{*}$ & 0.2209 & $0.0447^{*}$ \\
\hline \multirow[t]{4}{*}{$\mathrm{C} 6 \mathrm{~F}$} & a & -0.0319 & -0.523 & -1.73 & -0.205 & 0.254 & -0.00381 \\
\hline & $\mathrm{b}$ & 1.54 & 14.9 & 103.4 & 10.0 & 69.1 & 0.150 \\
\hline & $r^{2}$ & 0.676 & 0.880 & 0.575 & 0.753 & 0.0127 & 0.456 \\
\hline & $\mathrm{p}$ & $0.0445^{*}$ & $0.0056^{*}$ & 0.0804 & $0.0251^{*}$ & 0.8317 & 0.1412 \\
\hline
\end{tabular}

N3 sample, is shown in Fig. 3. All treatments followed a sigmoidal pattern of size increase whereby growth rates declined over time from maximal rates in the naupliar and early copepodite stages to minimal rates at C5. At excess food concentrations, protein and DNA content increased nearly exponentially during naupliar development and the first few copepodite stages, but began to slow down at about $\mathrm{C} 3$ (Fig. 3B,D). At the limiting food concentrations, the pattern was similar, but with slightly lower slopes (Fig. 3A,C).

Protein- and DNA-specific growth rates over time in the 3 food treatments at $8^{\circ} \mathrm{C}$ are shown in Fig. 4 . Growth rates in the food-limited treatments, especially the low food treatment, were extremely variable (Fig. 4B,C,E,F). Some of this variability undoubtedly resulted from sampling error; however, since we were unable to perfectly control the food concentration in these tanks, the growth rates in the food-limited treatments were truly changing on the scale of sampling. In order to avoid the risk of overlooking real fluctuations in growth rates in the medium and low food treatments which might correspond to changes in RNA concentration, we chose to present the growth rates calculated between points rather than to smooth the data to reduce sampling error.

Although it seems that food concentration affected growth rates of the younger stages more strongly than those of later stages (Fig. 4), this is only because the declining pattern of growth rates over time makes the absolute growth rates of the later stages appear more similar. When expressed relative to the corresponding rates in excess food, growth rates in the food-limited treatments were depressed more strongly during the copepodite stages than during the naupliar stages (data not shown). These results agree with those of Campbell et al. (2001, their Table 4) who found that nitrogen growth, and especially carbon growth, were more strongly limited in the later developmental stages.

Protein- and DNA-specific growth rates over time in the 3 temperature treatments are shown in Fig. 5. 
Fig. 3. Calanus finmarchicus. Mean $(\mathrm{A}, \mathrm{B})$ protein content and $(\mathrm{C}, \mathrm{D}) \mathrm{DNA}$ content as a function of age for Stages N3 through to adult. Left panels: effect of the 3 food treatments at $8^{\circ} \mathrm{C}_{\text {; }}$ right panels: effect of temperature with excess food. Lines show sigmoidal Chapman-Richards equations fit to the protein-age and DNA-age data for each treatment: $W=W_{\max }\left(1+B e^{-\mathrm{k} t}\right)^{-\mathrm{m}}$, where $W$ is the mean protein or DNA content at time $t$, the asymptote value $W_{\max }$ represents the size at maturity, $B$ represents the initial size, and $\mathrm{k}$ and $\mathrm{m}$ define the slope and inflection point of the curve respectively (after Vidal 1980)
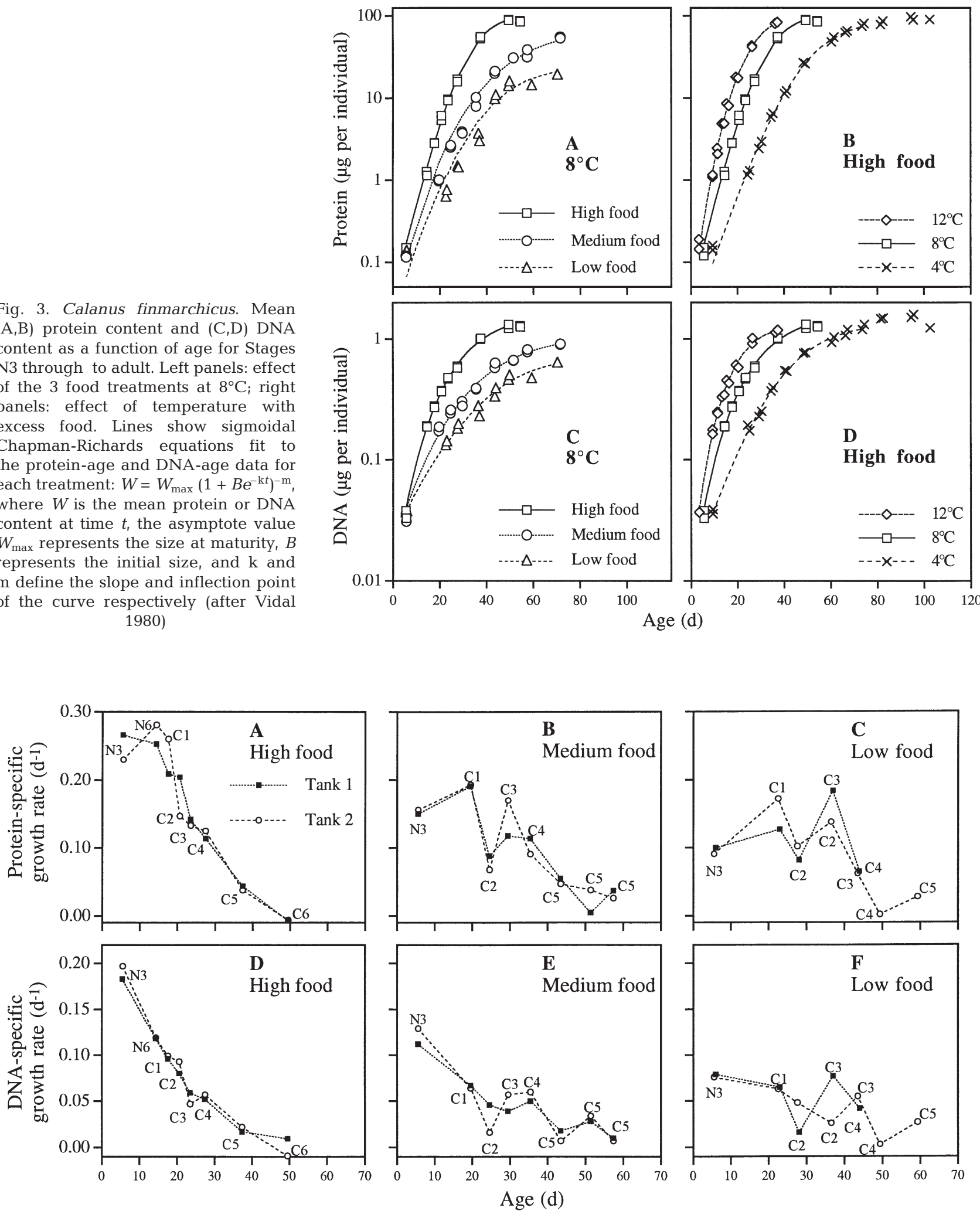

Fig. 4. Calanus finmarchicus. Growth rates in terms of protein and DNA in the 3 food treatments at $8^{\circ} \mathrm{C}$. Symbols show growth rates estimated between each sample and the next using Eq. (1). Stages that dominated the biomass of each sample are indicated on each panel 

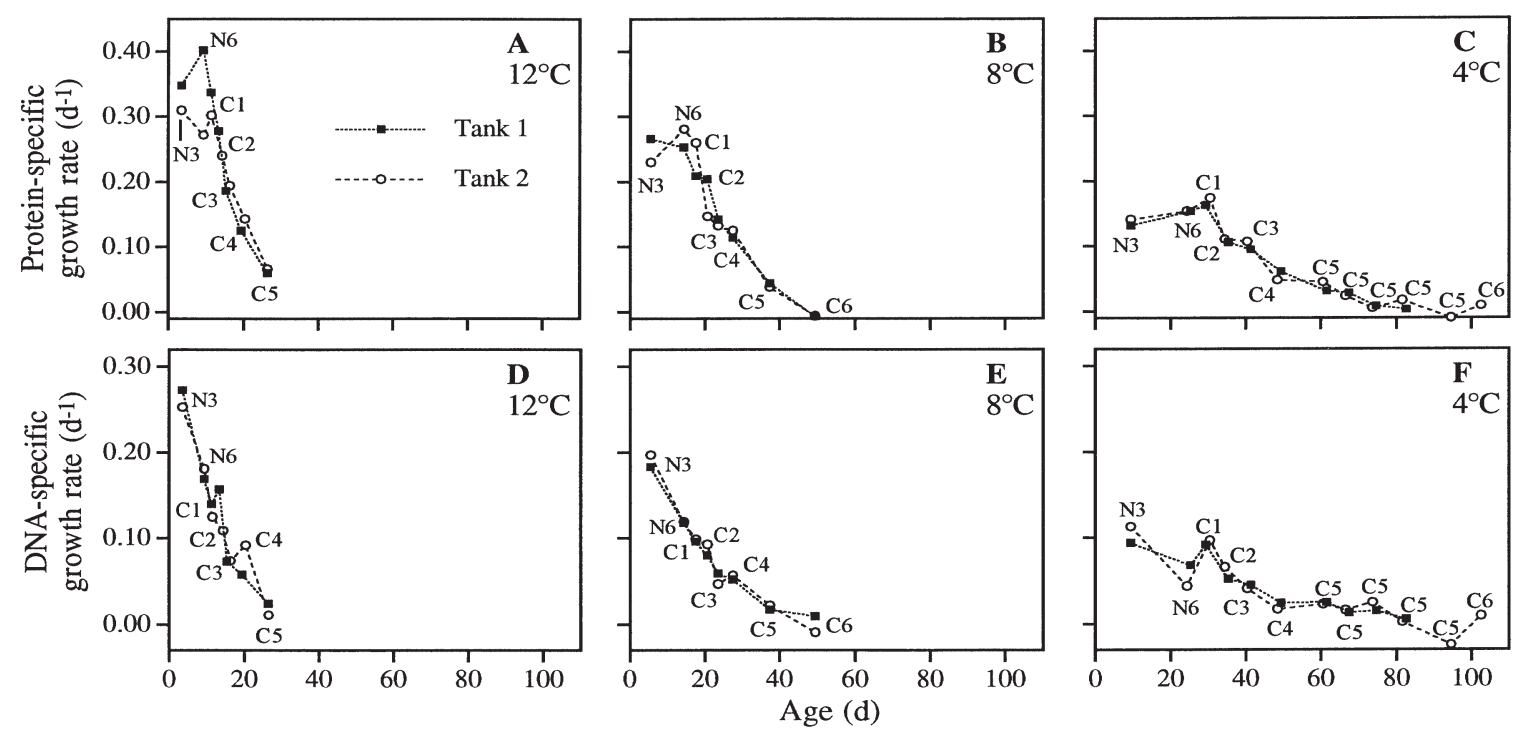

Fig. 5. Calanus finmarchicus. Growth rates in terms of protein and DNA in the 3 temperature treatments with excess food. Symbols show growth rates estimated between each sample and the next using Eq. (1). Stages that dominated the biomass of each sample are indicated on each panel

\section{Relationship of growth rates to biochemical ratios}

\section{Growth rates and RNA:DNA}

Because RNA:DNA ratios increased with increasing stage while growth rates declined (Figs 1D \& 4), it is clear that any relationship between the two is stagespecific and must be calibrated for each stage. Because our growth rates were measured on the whole population rather than on separate stages, we could not undertake this type of calibration. In fact, with populations of mixed stages it is only possible to obtain stagespecific growth rates by subsampling and incubation of individual stages.

We examined the relationship between growth rates and RNA:DNA ratios by normalizing for the effect of stage on both variables. Carbon and protein growth rates of Stages N6 through C5 from the 3 food treatments at $8^{\circ} \mathrm{C}$ were expressed relative to the average growth rate of each stage or combination of stages at high food $\left(G_{\max }\right)$. A relative RNA:DNA index (RRD) was calculated for each sample in a similar manner, using the mean RNA:DNA ratios of each stage in the high food treatment as $R D_{\max }$. The RRD index was a good predictor of relative carbon and protein growth, accounting for ca $70 \%$ of the variance in growth rates (Fig. 6). In this case 'hindcast' growth rates (i.e. those associated with the interval before sampling) were better correlated with relative RNA:DNA than were growth rates associated with the interval after sampling. Relative RNA:DNA values and relative growth rates exceeded $100 \%$ in the high food treatment
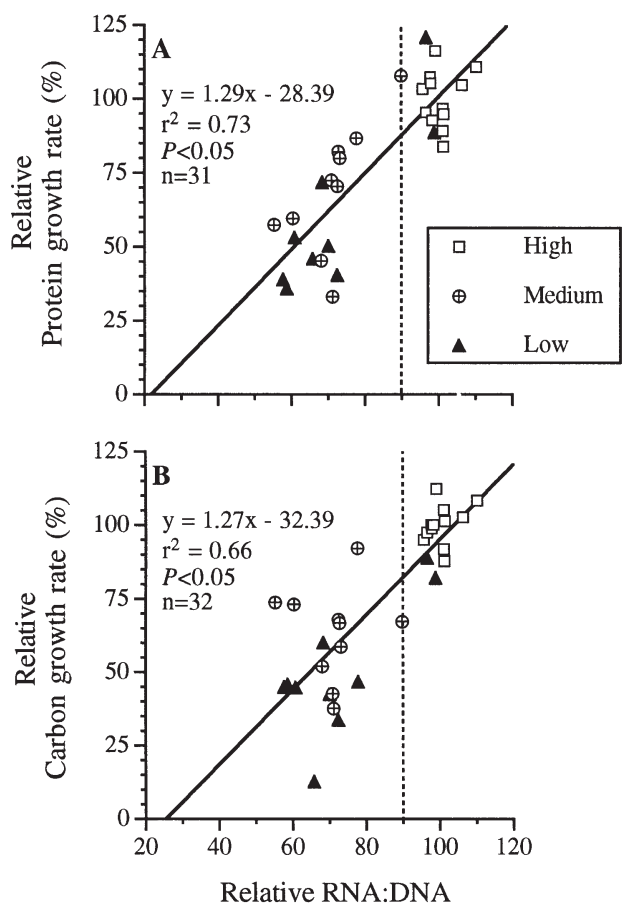

Fig. 6. Calanus finmarchicus. Relationship between relative growth rates and relative RNA:DNA in Stages N6 through to $\mathrm{C} 5$ reared at $8^{\circ} \mathrm{C}$ at 3 food concentrations. Dashed lines indicate the threshold between excess-food and food-limited growth

because they were standardized to the mean of the 2 tanks in the high food treatment rather than to the absolute maximum values observed. Since the lowest RRD values observed in the high food treatment were 
88 to $90 \%$, the division between food-limited and maximum growth occurred at a RRD of about $90 \%$. When food levels in the medium and low food treatments deviated from the

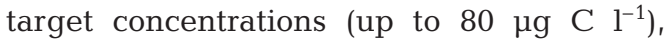
RNA:DNA and protein and carbon growth rates increased to values approaching those in the high food treatment (Fig. 6).

\section{Growth rates and RNA:protein.}

Except during the interval from N6 to $\mathrm{C} 1$, the trend of RNA:protein over the life cycle was in the same direction as that of growth, suggesting that this parameter would be useful as a growth rate index across stages, for all stages but N6 (Figs 1F \& 5; Campbell et al. 2001, their Fig. 11). Within one temperature $\left(8^{\circ} \mathrm{C}\right)$, growth rates of Stages C1 to C5 were significantly related to RNA:protein ( $p=0.0001$, Fig. 7). The trend was mainly ontogenetic, with earlier stages having higher growth rates and higher RNA:protein and older stages having lower values of both parameters. Analysis of covariance (ANCOVA) revealed that for protein, nitrogen, and DNA growth food concentration did not significantly alter the slopes or intercepts of the growth-RNA:protein regressions ( $p>$ 0.05, Fig. 7). This indicates that the linear relationship of growth rate to RNA:protein was similar in all 3 food treatments. Instead, the data points from the food-limited treatments shifted closer to the origin. For example, the growth rates and RNA:protein ratios of Stage $\mathrm{C} 1$ in the low food treatment were similar to those of C3 in excess food conditions, and the growth rates and RNA:protein ratios of $\mathrm{C} 3$ in the low food treatment were similar to C4 or C5 in excess food conditions. For carbon growth, however, the slope and intercept of the relationship of growth rate to RNA:protein was significantly different among the food treatments (ANCOVA, p $<0.05$, Fig. 7).

In Stages C1 to C5 reared at high food concentrations, the effect of temperature on the relationship of growth rates to RNA:protein was nonlinear (Fig. 8). Temperature altered the slope of the growth rateRNA:protein relationship so that at higher temperatures greater specific growth rates were associated with a given RNA:protein ratio. The increase was greater between 8 and $12^{\circ} \mathrm{C}$ than between 4 and $8^{\circ} \mathrm{C}$. This nonlinear effect of temperature was modeled by including a term for the interaction of RNA:protein and temperature in a multiple regression model:

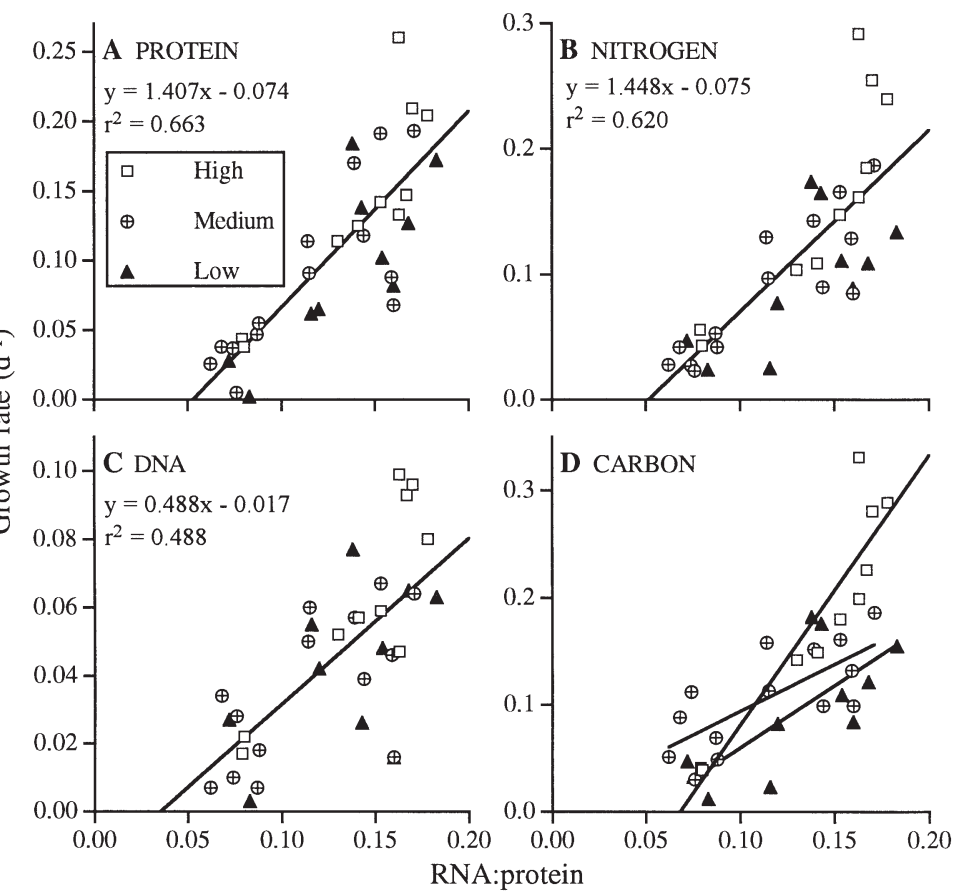

Fig. 7. Calanus finmarchicus. Growth rates as a function of RNA:protein for Stages $\mathrm{C} 1$ through $\mathrm{C} 5$ reared at 3 food concentrations at $8^{\circ} \mathrm{C}$. Growth rates were estimated from exponential increase in mean content of (A) protein, (B) nitrogen, (C) DNA, or (D) carbon between samples. Least-squares regressions were fit to all data for protein, nitrogen, and DNA growth, where there was no significant effect of food level on the slopes or $y$-intercepts (ANCOVA, p > 0.05). For carbon growth the slopes and intercepts of the regressions differed among food levels (ANCOVA, p < 0.05) and all 3 relationships are shown

$$
g=\mathrm{a}(\text { RNA:protein })+\mathrm{b}(\text { RNA:protein } \times T)+\mathrm{c}
$$

where $g$ is the growth rate $\left(\mathrm{d}^{-1}\right)$ in terms of protein, carbon, nitrogen, or DNA. Results of fits of this model to the data for the 4 methods of estimating growth are presented in Table 2. The effects of both RNA:protein and the RNA:protein $\times T$ (temperature) interaction were significant ( $p \ll 0.05$ ), and the multiple regression models explained 75 to $91 \%$ of the variance in growth rates.

\section{DISCUSSION}

\section{Effects of temperature and food on biochemical composition of Calanus finmarchicus}

In this experiment, temperature inversely affected protein and DNA content per individual from C2 onward. This result agrees with previous field work which found inverse relationships of length or weight to environmental temperature in many species of 


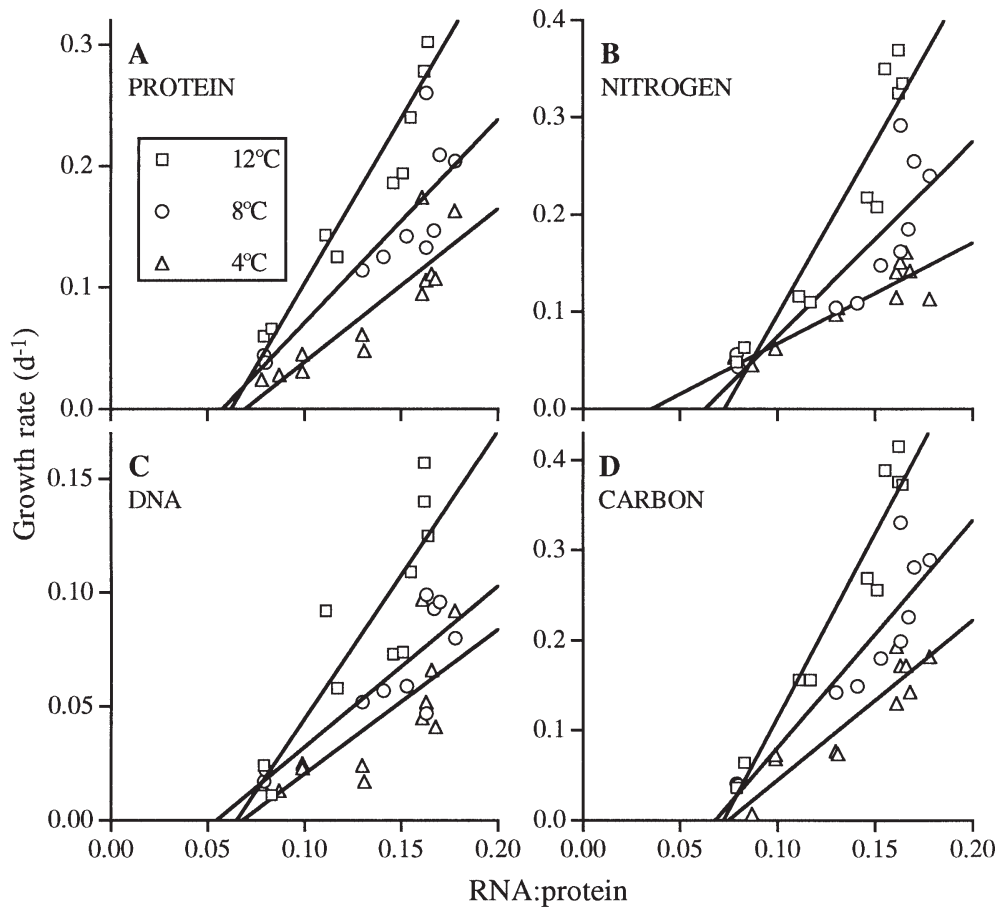

Fig. 8. Calanus finmarchicus. Growth rates as a function of RNA:protein for Stages C1 through C5 reared in the 3 temperature treatments with excess food. Growth rates were estimated from exponential increase in mean content of (A) protein, (B) nitrogen, (C) DNA, or (D) carbon between samples. Lines show the relationship of growth rates to RNA:protein at each temperature
Stages C5 and C6F was 165 and 248\% greater in excess food, respectively. The DNA content of adult females was nearly doubled in excess food conditions. Since the cumulative effect of low food concentrations on the structural weight was so much larger than the effect of temperature, these observations support the suggestion of Klein Breteler \& Gonzalez (1982) that food can be more important than temperature in determining body size and that the apparent relationship of body size to temperature in nature may be due to the confounding effect of lower food concentrations occurring with higher temperatures.

\section{DNA content as an index of cell number}

DNA content is considered to be an index of cell number (Bulow 1987), as all cells are assumed to contain the same amount of DNA (the nuclear and mitochondrial genomes). Based on this assumption, which has also been applied to work with other crustaceans (e.g. Anger \& Hirche 1990, Juinio et al. 1992), variable DNA content among treatments in the present study implies differences in total cell number. However in copepods it may be copepods (e.g. Deevey 1960, McLaren 1965, Durbin \& Durbin 1978). We estimate that the total protein content of copepodite stages was 26 to $50 \%$ greater and the DNA content 13 to $29 \%$ greater at $4^{\circ} \mathrm{C}$ than at $12^{\circ} \mathrm{C}$. Miller et al. (1977) suggested that the inverse relationship of body size with temperature results from differential effects of temperature on growth rates and molting rates, so that growth can be regulated to remain more constant than molting over the range of temperatures encountered by a species. Since one would expect protein growth to follow this pattern, the difference in structural weight (protein) of Calanus finmarchicus with temperature in the present study is no surprise.

Food limitation had a dramatic effect on protein and DNA content of Calanus finmarchicus. This effect was apparent beginning with Stage N6 and was especially strong for C5 and C6 females (Fig. 1A,C). The protein content of Stages C1 to C4 was 44 to $85 \%$ higher in the excess food treatment than in the lowest food treatment, and the protein content of
Table 2. Calanus finmarchicus. Multiple regression of growth rates against RNA:protein and temperature for copepodite stages reared at 3 temperatures with excess food. Regression parameters are given along with their standard errors. All parameters were statistically significant from 0 ( $p<0.05)$. Model: growth rate $=\mathrm{a}($ RNA:protein $)+\mathrm{b}($ RNA:protein $\times T)+\mathrm{c} ; \mathrm{n}=32$

\begin{tabular}{|lccccc|}
\hline $\begin{array}{l}\text { Growth } \\
\text { measure }\end{array}$ & $\mathrm{p}$ & $\mathrm{r}^{2}$ & $\mathrm{a}$ & $\mathrm{b}$ & $\mathrm{c}$ \\
\hline Protein & 0.0001 & 0.858 & $0.956 \pm 0.197$ & $0.110 \pm 0.012$ & $-0.111 \pm 0.024$ \\
DNA & 0.0001 & 0.750 & $0.488 \pm 0.121$ & $0.044 \pm 0.008$ & $-0.051 \pm 0.015$ \\
Nitrogen & 0.0001 & 0.857 & $1.208 \pm 0.240$ & $0.131 \pm 0.016$ & $-0.155 \pm 0.030$ \\
Carbon & 0.0001 & 0.902 & $1.549 \pm 0.227$ & $0.145 \pm 0.015$ & $-0.189 \pm 0.028$ \\
\hline
\end{tabular}


If cell number is in fact determinate in Calanus finmarchicus, the differences in DNA content among copepods in the different food and temperature treatments of the present study must result from differences in the nuclear DNA content rather than the total number of nuclei. The observed differences may possibly be due to timing of sampling within the molt cycle, as cell number increases throughout each stage (McLaren \& Marcogliese 1983). However, it is unlikely that the trend of higher DNA content in all stages at higher food concentrations and cooler temperatures results from sample timing, as this would mean that the treatment tanks that produced copepods with higher DNA content were consistently sampled later in the molt cycle. In their paper describing the DNA content per nucleus of adult females of 7 Calanus species, McLaren et al. (1988) noted that the DNA content of $C$. finmarchicus per cell was approximately $13 \mathrm{pg}$, but could vary significantly among females and with season or treatment. This suggests that caution is required when DNA content is to be interpreted as a cellnumber index. At this time it is unclear to us to what extent differences in cell number or cellular DNA content are responsible for our observed differences in DNA content.

The uncertainty about whether DNA content is truly an index of cell number has implications for the interpretation of biochemical ratios. As such, the RNA:DNA and protein:DNA ratios may not reflect the true RNA or protein content per cell, but could underestimate the disparity among treatments in cell size or condition. In other words, increased DNA per cell means that RNA:DNA ratio is less than the true RNA content per cell. Nevertheless, the fact that in the present study the RNA:DNA ratio was strongly related to food concentration and temperature suggests that its application is not likely to be impaired by any confusion surrounding the use of DNA as a cell-number index.

\section{RNA as a growth rate index}

RNA:DNA was the only biochemical ratio that was clearly related to temperature and food availability. The effects of temperature and food on RNA:DNA in this study were similar to the results of Ota \& Landry (1984), who found that RNA:DNA ratios of Calanus pacificus were reduced at lower food concentrations and higher temperatures. The effects of temperature and food on protein:DNA and RNA:protein ratios were less clear; these ratios were higher in the high food treatment and showed inverse trends with temperature, but these differences were significant in fewer than half of the stages investigated.
Since temperature had a strong positive effect on growth rates, but a weaker inverse effect (or no effect at all) on RNA:DNA and RNA:protein ratios, temperature effects must clearly be considered in any model for estimating growth from RNA concentration. This is likely to be true for any biochemical growth rate-index; increased chemical reaction rates at higher temperatures mean that lower enzyme or RNA concentrations can be associated with higher growth rates.

Based on its strong response to reduced food conditions (Fig. 1D), RNA:DNA ratio seems to be the most sensitive growth-rate index. Although stage-specific models for estimating growth rates directly from RNA:DNA ratio could not be constructed from the data presented here, the results from the present work demonstrate that RNA:DNA ratio is a useful index of nutritional condition and relative growth rates. Standardizing for the effects of temperature and developmental stage on RNA:DNA ratio and growth rates offers a useful tool for estimating relative growth rates in the field. At $8^{\circ} \mathrm{C}$, the relative RNA:DNA index (RRD) was strongly related to relative carbon and protein growth rates (Fig. 6). Although one should be cautious when working with copepods living at other temperatures, the relationships shown in Fig. 6 should apply to temperatures other than $8^{\circ} \mathrm{C}$, since reduced RNA:DNA ratios are likely to be associated with reduced growth rates at any temperature. RRD can be calculated for Calanus finmarchicus in the field by the following formula:

$$
\mathrm{RRD}=\frac{\mathrm{RNA}: \mathrm{DNA}_{\text {field }}}{\mathrm{RNA}: \mathrm{DNA}_{\mathrm{ST}}} \times 100
$$

where RNA:DNA $\mathrm{ST}_{\mathrm{ST}}$ is the average RNA:DNA ratio expected under excess food conditions at the in situ temperature and is calculated from the regression models for RNA:DNA as a function of temperature (Table 1). Relative growth rates (protein or carbon) can then be estimated by the regressions shown in Fig. 6 . Relative growth rates provide direct comparison to maximal rates for a given stage and temperature, and can be converted back to specific growth rates. However because temperature has such a profound effect on growth rates, accurate estimates of the temperature environment experienced by the copepods are essential.

In this experiment, RNA:protein ratio was not significantly different among food levels in most cases, but did reflect growth rates during the copepodite stages. Food level did not significantly affect the relationship of growth rate of structural components (protein, N, DNA) to RNA:protein ratio, but the slope of the relationship of carbon growth to RNA:protein ratio was reduced in the food-limited treatments (Fig. 7). This is evidence that storage growth was reduced rela- 
tive to structural growth in these treatments. Our results suggest that because RNA:protein ratio is an index of the rate of increase in protein content, it is best used as an index of structural growth in lipid-storing species like Calanus finmarchicus.

Our models for growth rates as a function of RNA:protein ratio and temperature (Fig. 8, Table 2) were identical in form to the model developed by Saiz et al. (1998) for egg production rates of female Acartia grani as a function of RNA:DNA ratios and temperature. In both cases, increasing the temperature dramatically increased the growth rate or egg production rate achieved at a given RNA concentration, especially in copepods with the highest ratios.

RNA:protein ratios were good predictors of structural growth rates, especially when used together with temperature, and offer another way of estimating growth rates of natural populations of Calanus finmarchicus. The models presented in Table 2 for growth rates as a function of RNA:protein ratio and temperature in the high food treatments could be used to estimate growth rates under food-limited conditions. There was no effect of food on the relationship of protein, nitrogen, or DNA growth rates to RNA:protein ratio at $8^{\circ} \mathrm{C}$ (Fig. 7 ), and it is likely that there is no effect at other temperatures so that growth rates can be directly estimated from RNA:protein ratio and temperature without regard for developmental stage or food conditions.

RNA concentration offers 2 useful techniques for estimating growth rates of Calanus finmarchicus in the field; each method has strengths and limitations. The RNA:DNA ratio is stage-specific; however with compensation for developmental stage and temperature the RRD shows a strong relationship to relative growth rates under different food conditions. Since standardizing to the maxima for each stage removes differential effects on RNA and growth rate of each stage, the RRD can be used to estimate carbon growth rates and is useful for Stage N6. Although in this study the relative RNA:DNA index was only calibrated for Stages N6 to C5, it should be useful for the earlier naupliar stages as well, if maximal RNA:DNA ratios and growth rates are measured for those stages in the future.

The relationship of RNA:protein ratio to growth rates is not stage-specific, and therefore shows promise as a population-level growth rate index for Calanus finmarchicus, since it provides a direct estimate of growth rate from RNA:protein ratio and temperature. However, in copepods which store large quantities of lipid, the RNA:protein ratio is a reliable index of structural growth only, and in this study its relation to growth rate under food-limited conditions was weaker than that of relative RNA:DNA index $\left(\mathrm{r}^{2}=0.49\right.$ to $0.66 \mathrm{vs}$ 0.66 to 0.73 ). Since the relationship between growth rate and RNA:protein differs during N6 from that during other stages, this method has been calibrated for copepodite stages only. With additional calibration, the RNA:protein method could likely be applied to the earlier naupliar stages, but should not be used to estimate growth rates during the N6-C1 interval.

Acknowledgements. We wish to thank Lawrence Buckley and Elaine Caldarone of NOAA-NMFS for use of the biochemistry laboratory at the NMFS Narragansett Laboratory and for instructive comments on the experiment and on the manuscript. The comments of Saran Twombly and 4 anonymous reviewers helped to improve the manuscript significantly; their help is appreciated. This work was supported by NSF (projects OCE-9313677, OCE-9632460, and OCE9806506) as part of the US GLOBEC Georges Bank Program and is US GLOBEC contribution number 191.

\section{LITERATURE CITED}

Anger K, Hirche HJ (1990) Nucleic acids and growth of larval and early juvenile spider crab, Hyas araneus. Mar Biol 105:403-411

Båmstedt U (1983) RNA concentrations in zooplankton: seasonal variation in boreal species. Mar Ecol Prog Ser 11: 291-297

Båmstedt U, Skjoldal HR (1976) Studies on the deep-water pelagic community of Korsfjorden, Western Norway: adenosine phosphates and nucleic acids in Euchaeta norvegica (Copepoda) in relation to its life cycle. Sarsia 60:63-80

Båmstedt U, Skjoldal HR (1980) RNA concentration of zooplankton: relationship with size and growth. Limnol Oceanogr 25:304-316

Berdalet E, Dortch Q (1991) New double-staining technique for RNA and DNA measurement in marine phytoplankton. Mar Ecol Prog Ser 73:295-305

Buckley LJ (1984) RNA-DNA ratio: an index of larval fish growth in the sea. Mar Biol 80:291-298

Buckley L, Caldarone E, Ong TL (1999) RNA-DNA ratio and other nucleic acid-based indicators for growth and condition of marine fishes. Hydrobiologia 401:265-277

Bulow FJ (1987) RNA-DNA ratios as indicators of growth in fish: a review. In: Summerfelt RC, Hall GC (eds) The age and growth of fish. The Iowa State University Press, Ames, IA

Caldarone E, Buckley LJ (1991) Quantitation of DNA and RNA in crude tissue extracts by flow injection analysis. Anal Biochem 100:188-197

Campbell RG, Wagner MM, Teegarden GJ, Boudreau CA, Durbin EG (2001) Growth and development of the copepod Calanus finmarchicus reared in the laboratory. Mar Ecol Prog Ser 221:161-183

Clemmesen C (1993) Improvements in the fluorimetric determination of the RNA and DNA content of individual marine fish larvae. Mar Ecol Prog Ser 100:177-183

Dagg MJ, Littlepage JL (1972) Relationships between growth rate and RNA, DNA, protein and dry weight in Artemia salina and Euchaeta elongata. Mar Biol 17:162-170

Deevey GB (1960) Relative effects of temperature and food on seasonal variations in length of marine copepods in some eastern American and western European waters. Bull Bingham Oceanogr Coll Yale Univ17:55-86

Durbin EG, Durbin AG (1978) Length and weight relation- 
ships of Acartia clausi from Narragansett Bay, R.I. Limnol Oceanogr 23:958-969

Frantzis A, Grémare A, Vétion G (1992) Growth rates and RNA:DNA ratios in Paracentrotus lividus (Echinodermata: Echinoidea) fed on benthic macrophytes. J Exp Mar Biol Ecol 156:125-138

GLOBEC (1992) Northwest Atlantic Implementation Plan. Report No. 6. US Globel, Davis, CA

Goolish EM, Barron MG, Adelman IR (1984) Thermoacclimatory response of nucleic acid and protein content of carp muscle tissue: influence of growth rate and relationship to glycine uptake by scales. Can J Zool 62:2164-2170

Juinio MAR, Cobb JS, Bengtson D, Johnson M (1992) Changes in nucleic acids over the molt cycle in relation to food availability and temperature in Homarus americanus postlarvae. Mar Biol 114:1-10

Klein Breteler WCM, Gonzalez SR (1982) Influence of cultivation and food concentration on body length of calanoid copepods. Mar Biol 71:157-161

Mayrand E, Guderley H, Dutil JD (1998) Effect of morphometric maturity and size on enzyme activities and nucleic acid ratios in the snow crab Chionoecetes opilio. J Crustac Biol 18(2):232-242

McLaren IA (1965) Some relationships between temperature and egg size, body size, developmental rate, and fecundity of the copepod Pseudocalanus. Limnol Oceanogr 10: 528-538

McLaren IA, Marcogliese DJ (1983) Similar nucleus numbers among copepods. Can J Zool 61:721-724

McLaren IA, Sevigny JM, Corkett CJ (1988) Body sizes, development rates, and genome sizes among Calanus species. Hydrobiologia 167/168:275-284

Miller CB, Johnson JK, Heinle DR (1977) Growth rules in the marine copepod genus Acartia. Limnol Oceanogr 22: 326-335

Nakata K, Nakano H, Kikuchi H (1994) Relationship between egg productivity and RNA/DNA ratio in Paracalanus sp in the frontal waters of the Kuroshio. Mar Biol 119:591-596

Editorial responsibility: Kenneth Sherman (Contributing Editor), Narragansett, Rhode Island, USA
Olson CS, Clegg JS (1978) Cell division during development of Artemia salina. Wilhelm Roux's Arch Dev Biol 184:1-13

Ota AY, Landry MR (1984) Nucleic acids as growth rate indicators for early developmental stages of Calanus pacificus Brodsky. J Exp Mar Biol Ecol 80:147-160

Paffenhöfer GA, Harris RP (1979) Laboratory culture of marine holozooplankton and its contribution to studies of marine planktonic food webs. Adv Mar Biol 16:211-308

Saiz E, Calbet A, Fara A, Berdalet E (1998) RNA content of copepods as a tool for determining adult growth rates in the field. Limnol Oceanogr 43:465-470

Smith PK, Krohn RI, Hermanson GT, Mallia AK, Gartner FH, Provenzano MD, Fujimoto EK, Goeke NM, Olson BJ, Klenk DC (1985) Measurement of protein using bicinchoninic acid. Anal Biochem 150:16-85

Sulkin SD, Morgan RP II, Minasian LL Jr (1975) Biochemical changes during larval development of the xanthid crab Rhithropanopeus harrisii. II. Nucleic acids. Mar Biol 32: 113-117

Sutcliffe WH Jr (1965) Growth estimates from ribonucleic acid content in some small organisms. Limnol Oceanogr 10(Suppl): R253-R258

Sutcliffe WH Jr (1969) Relationship between growth rate and ribonucleic acid concentration in some invertebrates. J Fish Res Board Can 27:606-609

Thorpe JE, Talbot C, Villarreal C (1982) Bimodality of growth and smolting in Atlantic salmon, Salmo salar L. Aquaculture 28:123-132

Vidal J (1980) Physioecology of zooplankton. I. Effects of phytoplankton concentration, temperature, and body size on the growth rate of Calanus pacificus and Pseudocalanus sp. Mar Biol 56:111-134

Wagner MM, Durbin EG, Buckley LJ (1998) RNA:DNA ratios as indicators of nutritional condition in the copepod Calanus finmarchicus. Mar Ecol Prog Ser 162:173-181

Wright DA, Hetzel EW (1985) Use of RNA:DNA ratios as an indicator of nutritional stress in the American oyster Crassostrea virginica. Mar Ecol Prog Ser 25:199-206

Submitted: March 10, 2000; Accepted: January 17, 2001

Proofs received from author(s): September 25, 2001 